\title{
SHORT TERM FASTING DOES NOT AGGRAVATE IMMUNOSUPPRESSION IN HARBOUR SEALS (PHOCA VITULINA) WITH HIGH BODY BURDENS OF ORGANOCHLORINES
}

\author{
R.L. de Swart ${ }^{1,4}$, P.S. Ross ${ }^{1,2}$, H.H. Timmerman', W.C. Hijman ${ }^{2}$, E.M. de Ruiter ${ }^{3}$, A.K.D. Liem², A. \\ Brouwer $^{5}$, H. van Loveren', P.J.H. Reijnders ${ }^{3}$, J.G. Vos ${ }^{2}$ and A.D.M.E. Osterhaus ${ }^{1,4}$ \\ 1: Seal Rehabilitation and Research Centre, Hoofdstraat 94a, Pieterburen \\ 2: National Institute of Public Health and Environmental Protection, P.O. Box 1, Bilthoven \\ 3: DLO-Institute for Forestry and Nature Research, P.O. Box 167, Den Burg \\ 4: Institute of Virology, Erasmus University, P.O. Box 1738, Rotterdam \\ 5: Agricultural University of Wageningen, P.O. Box 8000, Wageningen \\ THE NETHERLANDS
}

(Received in Sweden 6 September 1995; accepted 2 October 1995)

\begin{abstract}
Two groups of 11 harbour seals (Phoca vitulina) with different body burdens of organochlorines were subjected to an experimental 15-day fasting period, during which they lost an average $16.5 \%$ of their body weights. Blood levels of the most persistent organochlorines showed an approximate twofold increase, while levels of aryl hydrocarbon receptor-binding organochlorines remained largely unaffected. Few differences in immunological parameters were observed between the two dietary groups. Numbers of circulating lymphocytes dropped to about $65 \%$ of the initial values and NK cell activity showed a slight increase in both groups. Mitogen- and antigen-induced lymphoproliferative responses of the Baltic group of seals remained within normal ranges. These results suggest that relatively short-term fasting periods do not present an additional immunotoxicological risk to seals with high body burdens of organochlorines.
\end{abstract}

\section{INTRODUCTION}

Fasting periods are a normal phenomenon in the natural life history of seals, and may occur in relation to their reproductive cycle or the moulting season (Costa, 1995). The lengths of these periods of partial or total food deprivation may vary from one or two weeks up to more than three months, during which the animals may lose more than $40 \%$ of their body mass (Costa and Ortiz, 1982; Costa et al. 1986; Bowen et al. 1992). True seals are physiologically adapted to long fasting periods. Metabolization of lipids from their blubber supplies most of their energy- and water requirements, thus limiting protein oxidation (Ortiz et al. 1978; Bowen et al. 1992; Castellini and Rea, 1992; Rea and Costa, 1992; Nordoy et al. 1993). Serum levels of ketone bodies, which serve as energy source for the central nervous system during fasting periods, never reach levels which could affect the acid-base balance leading to metabolic acidosis or ketosis, as is seen in non-adapted mammalian species during prolonged fasting (Castellini and Rea, 1992). 
Although seals are adapted to fasting, the risk posed by the release of anthropogenic chemicals from their lipid reserves during these episodes may be of concern, since marine mammals inhabiting polluted marine areas carry high body burdens of lipophilic environmental contaminants (Tanabe et al. 1983; Hutchinson and Simmonds, 1994). Chronic contaminant exposure has been associated with a number of adverse biological effects in marine mammals, including skeletal deformations (Bergman et al. 1992; Mortensen et al. 1992), reproductive toxicity (Helle et al. 1976a; Helle et al. 1976b; Reijnders, 1986), hormonal alterations (Brouwer et al. 1989; Subramanian et al. 1987), and immunotoxicity (De Swart et al. 1994; De Swart et al. 1995b; Ross et al. 1995a; Ross et al. 1995b). Recent morbillivirus related mass mortalities among marine mammals inhabiting polluted coastal waters (Visser et al. 1993; De Swart et al. 1995a) led to speculation about a possible contribution of environmental contaminant-induced immunosuppression to the severity and extent of these epizootics (Osterhaus and Vedder, 1989; Simmonds and Johnston, 1989). Epidemiological studies showed high levels of potentially immunotoxic contaminants in animals affected by the morbillivirus outbreaks (Hall et al. 1992; Aguilar and Borrell, 1994), although a causal involvement of pollution in the epizootics could not conclusively be demonstrated (Kuiken et al. 1994; Olsson et al. 1994).

We carried out an immunotoxicological study in which captive young harbour seals (Phoca vitulina) were fed fish contaminated through the food chain of two different marine regions. During a $2 \frac{1}{2}$ year period, two groups of eleven seals were fed herring from the heavily polluted Baltic Sea or the relatively uncontaminated Atlantic Ocean, respectively. The long-term intake of contaminated herring led to significantly higher burdens of immunotoxic xenobiotics in the blubber and blood of the seals of the Baltic group (Ross et al. 1995a). We previously reported an impairment of immune function in this group of seals, as evidenced by suppressed natural killer (NK) cell activity and specific T lymphocyte mediated responses (De Swart et al. 1994; De Swart et al. 1995b; Ross et al. 1995a; Ross et al. 1995b).

In order to test the hypothesis that mobilization of contaminants during fasting periods might pose an additional immunotoxic risk, we subjected the two groups of seals to a 15-day fasting. Here we report the results of functional immunological assays carried out before, during and after this fasting experiment. The data are evaluated in the light of the levels of organochlorines measured in the fish, seal blubber and in blood samples taken before and during the fasting period.

\section{MATERIALS AND METHODS}

Animals - 22 harbour seals were caught as weaned pups from the north-east coast of Scotland, and fed relatively unpolluted herring for an adaptation period of one year. The seals were matched for weight and gender and divided over two groups, which were fed herring from the heavily polluted Baltic Sea or from the relatively uncontaminated Atlantic Ocean for a period of 126 weeks (this period will further be referred to as "feeding study"). From week 126 onward (end of February 1994), the seals were subjected to an experimental fasting period of 15 days (further referred to as "fasting experiment"). The two-week duration of the fasting experiment was chosen since free-ranging harbour seals are known to fast between 15 and 20 days under natural circumstances (Bowen et al. 1992), and an experimental fasting of similar length was previously carried out with 
harbour seals without adverse health effects (Markussen et al. 1992). The seals that had been fed Atlantic herring are further referred to as "Atlantic group", the seals that had been fed Baltic herring as "Baltic group". Following the fasting experiment, both groups were fed Atlantic herring ad libitum for a period of six months, after which they were released in the North Sea. The seals (seven females and four males in both groups) were housed at the Seal Rehabilitation and Research Centre in Pieterburen. At the beginning of the feeding study (week 0 ) the animals were approximately 15 months old, and at the moment of their release approximately 4 years. During captivity the seals were under veterinary supervision. This study was approved by the Animal Care Committee of the National Institute of Public Health and Environmental Protection in The Netherlands.

Diets - Composition and vitamin supplementation of herring diets have been described previously (De Swart et al. 1995c). Baltic herring was caught approximately $100 \mathrm{~km}$ off the southwest coast of Finland, while Atlantic herring was caught a few hundred $\mathrm{km}$ north of the British isles. Estimated daily intakes of potentially immunotoxic xenobiotics including polychlorinated biphenyls (PCBs), dibenzo-p-dioxins (PCDDs), and dibenzofurans (PCDFs), hexachlorobenzene (HCB), and the pesticides $\beta$-hexachloro-cyclohexane $(\beta-\mathrm{HCH})$, dieldrin and DDT, were three to more than ten times higher in the Baltic group (De Swart et al. 1994).

Chemical analyses - Chemical analyses were carried out on herring, seal blubber and seal blood. Random samples were taken from each batch of fish (in both groups three different batches were used during the course of the experiment), homogenated and frozen at $-20^{\circ} \mathrm{C}$. Blubber biopsies $( \pm 200 \mathrm{mg})$ were taken from all the seals at week 104 of the experiment as previously described (Ross et al. 1995a), and frozen at $-20^{\circ} \mathrm{C}$. Blood samples were taken six weeks before the fasting experiment ("pre", week 121), and at days 8 and 15 after the start of the fasting experiment. Blood was obtained from the epidural vein using a $18 \mathrm{G} 3 \frac{1}{2}(1.2 \times 90 \mathrm{~mm})$ spinal needle connected to a vacutainer tube holder with a luer lock adapter (Becton-Dickinson). For each animal, a total volume of approximately $15 \mathrm{ml}$ was collected into non-siliconized tubes without additives. Blood samples of the seals of both dietary groups taken on one day were pooled and stored at $-20^{\circ} \mathrm{C}$. Lipid content of Baltic herring was lower than that of Atlantic herring: $7.1 \%$ and $12.1 \%$, respectively (De Swart et al. 1994). Extractable lipid percentages ( \pm SE) of the blubber biopsies were $74 \pm 4 \%$ and $83 \pm 4 \%$ for biopsies obtained from the seals of the Atlantic or Baltic group, respectively (not significantly different by Student's $t$ test). Lipid percentages of the blood samples were $0.23 \%$ and $0.22 \%$ (pre), $0.25 \%$ and $0.23 \%$ (day 8 ) and $0.26 \%$ and $0.28 \%$ (day 15) for pooled blood samples obtained from the seals of the Atlantic or Baltic group, respectively. Organochlorine concentrations were determined on the basis of extractable lipid. Total and congener-specific levels of PCBs and DDTs, as well as dieldrin, $\mathrm{HCB}$ and $\beta-\mathrm{HCH}$ were measured as previously described (Boon et al. 1987). Congener-specific analysis of PCDDs, PCDFs and non-ortho chlorine substituted (coplanar) PCBs was carried out as previously described (Liem et al. 1990; Van der Velde et al. 1994). 2,3,7,8-tetrachlorodibenzo-p-dioxin (TCDD) toxic equivalents (TEQ) were calculated using toxic equivalency factors (TEF) as described (Van Zorge et al. 1989; Ahlborg et al. 1994), on the basis of levels of the seventeen 2,3,7,8-chlorine substituted PCDDs and PCDFs, and non-ortho chlorine substituted PCBs 77 (3,3', 4,4' 'TCB), 126 (3,3',4,4',5-

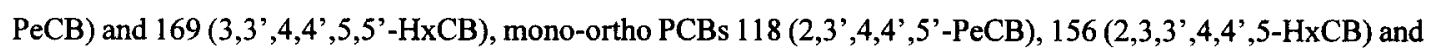

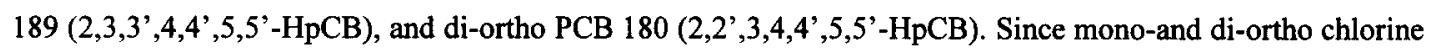


substituted PCBs were the major contributors to the total TEQ levels (Ross et al. 1995a), and PCBs 105, 114, $123,157,167$ and 170 could not be analyzed, this value probably represents an underestimation of the true TEQ levels. Levels of organotin compounds, including triphenyltin, tributyltin and cyhexatin, in herring and seal blood were measured in extractable lipid after pentylation using gas chromatography methods. Levels of dinitrophenol compounds in herring and seal blood were measured in extractable lipid using HPLC methods.

Estimation of cumulative intakes and body burdens of organochlorines - Cumulative organochlorine intakes were estimated by multiplying contaminant levels in herring (in $\mu \mathrm{g} / \mathrm{kg}$ lipid) with estimated daily lipid intakes (in $\mathrm{kg} / \mathrm{day}$ ), and multiplying this with the total duration of the feeding study (882 days). Lipid intakes were estimated at 0.45 and $0.4 \mathrm{~kg}_{\text {day }}{ }^{-1}$ for the Atlantic and Baltic groups respectively, based on estimated daily herring intakes and lipid percentages in herring (De Swart et al. 1995c). Mean body burdens were estimated

Table 1A: Organochlorine contaminants in herring, seal blubber and seal blood before the start of the fasting experiment: non $A h$ receptor-binding compounds.

\begin{tabular}{|c|c|c|c|c|c|c|}
\hline & \multicolumn{2}{|c|}{------herring'------ } & \multicolumn{2}{|c|}{-----seal blubber ${ }^{2}---$} & \multicolumn{2}{|c|}{--seal blood ${ }^{3}--$} \\
\hline & Atlantic & Baltic & Atlantic & Baltic & Atlantic & Baltic \\
\hline PCB52 ${ }^{4}$ & $12 \pm 3^{5}$ & $96 \pm 36$ & $67 \pm 7$ & $154 \pm 10$ & 65 & 92 \\
\hline PCB $138 / 163 / 164^{4}$ & $82 \pm 14$ & $442 \pm 19$ & $1417 \pm 52$ & $3429 \pm 233$ & 1168 & 2551 \\
\hline $\mathrm{PCB} 149^{4}$ & $55 \pm 12$ & $286 \pm 53$ & $352 \pm 12$ & $1075 \pm 82$ & 308 & 791 \\
\hline $\mathrm{PCB} 153^{4}$ & $106 \pm 28$ & $467 \pm 29$ & $1392 \pm 52$ & $3230 \pm 219$ & 1155 & 2496 \\
\hline sum PCBs & $875 \pm 158$ & $4398 \pm 715$ & $6884 \pm 493$ & $16488 \pm 1023$ & 7109 & 15062 \\
\hline sum DDTs & $152 \pm 23$ & $2155 \pm 807$ & $3050 \pm 420$ & $12690 \pm 1920$ & 788 & 2779 \\
\hline $\mathrm{p}, \mathrm{p}^{\prime}-\mathrm{DDT}$ & $31 \pm 3$ & $272 \pm 35$ & $306 \pm 55$ & $2448 \pm 368$ & 89 & 552 \\
\hline $\mathrm{HCB}$ & $21 \pm 4$ & $88 \pm 6$ & $12 \pm 2$ & $19 \pm 4$ & 30 & 86 \\
\hline$\beta-\mathrm{HCH}$ & $<10$ & $87 \pm 23$ & $<130$ & $<130$ & $<1$ & 12 \\
\hline
\end{tabular}

Legend to table 1: For a period of 128 weeks, two groups of harbour seals were fed herring from the heavily polluted Baltic Sea or the relatively uncontaminated Atlantic Ocean. At week 104, blubber samples were taken from all seals for chemical analyses. At week 121 blood samples were taken and mixed for each dietary group. Table $1 \mathrm{~A}$ shows levels of non- $A h$ receptor-binding organochlorines in herring, seal blubber and seal blood, while table $1 \mathrm{~B}$ shows levels of $A h$ receptor-binding organochlorines. 'means $\pm \mathrm{SE}$ of three batches of herring; ${ }^{2}$ means $\pm \mathrm{SE}$ of 11 seals; ${ }^{3}$ concentration in pooled blood sample of 11 seals; ${ }^{4}$ representative $\mathrm{PCB}$ congeners of $\mathrm{CB}$ classification-groups as proposed by Boon et al 1994 are shown: PCB 153 as representative of group I: congeners without vicinal hydrogen $(\mathrm{H})$ atoms; PCB 138/163/164 as representative of group II: congeners with vicinal $\mathrm{H}$ atoms in the ortho and meta positions in combination with $\geq 2$ ortho-chlorin (Cl) atoms; PCB 118 (table 1B) as representative of group III: congeners with vicinal $\mathrm{H}$ atoms in the ortho and meta positions in combination with 1 ortho-Cl atom; PCB 52 as representative of group IV: congeners with vicinal $\mathrm{H}$ atoms in the meta and para positions in combination with 2 ortho- $\mathrm{Cl}$ atoms; PCB 149 as representative of group V: congeners with viciwal $\mathrm{H}$ atoms in the meta and para positions in combination with $\geq 3$ ortho- $\mathrm{Cl}$ atoms ${ }^{5}$ levels shown in table $1 \mathrm{~A}$ are in $\mu \mathrm{g} \mathrm{kg}{ }^{-1} ;{ }^{6}$ levels shown in table $1 \mathrm{~B}$ are in $\mathrm{ng} \mathrm{kg}^{-1}$ lipid unless otherwise specified; ${ }^{6} \mathrm{~N} . \mathrm{D}$. not determined due to analytical error. 
Table 1B: Organochlorine contaminants in herring, seal blubber and seal blood before the start of the fasting experiment: $A h$ receptor-binding compounds.

\begin{tabular}{|c|c|c|c|c|c|c|}
\hline & \multicolumn{2}{|c|}{------herring'--..-- } & \multicolumn{2}{|c|}{---seal blubber²--- } & \multicolumn{2}{|c|}{---seal blood ${ }^{3}--$} \\
\hline & Atlantic & Baltic & Atlantic & Baltic & Atlantic & Baltic \\
\hline 2,3,7,8-TCDD & $1.6 \pm 0.2^{6}$ & $10.9 \pm 2.6$ & $<1$ & $<1$ & 2.4 & 2.1 \\
\hline 1,2,3,7,8-PeCDD & $4.6 \pm 0.3$ & $35.9 \pm 7.7$ & $<1$ & $<1$ & $<0.1$ & 3.8 \\
\hline $1,2,3,4,7,8-\mathrm{HxCDD}$ & $0.8 \pm 0.1$ & $4.2 \pm 0.9$ & $<1$ & $<1$ & $<0.1$ & 0.8 \\
\hline $1,2,3,6,7,8-\mathrm{HxCDD}$ & $2.8 \pm 0.2$ & $26.0 \pm 4.9$ & $5.0 \pm 0.3$ & $15.9 \pm 2$ & 3.5 & 9.1 \\
\hline 1,2,3,7,8,9-HxCDD & $0.8 \pm 0.1$ & $3.4 \pm 0.7$ & $<1$ & $<1$ & $<0.1$ & $<0.1$ \\
\hline $1,2,3,4,6,7,8-\mathrm{HpCDD}$ & $3.5 \pm 1.3$ & $8.4 \pm 2.8$ & $3.3 \pm 0.8$ & $7.8 \pm 1.8$ & 81.0 & 130.8 \\
\hline OCDD & $17 \pm 10$ & $58.9 \pm 29$ & $8.0 \pm 2.2$ & $23.9 \pm 5.9$ & 419.3 & 608.7 \\
\hline $2,3,7,8-\mathrm{TCDF}$ & $31 \pm 2$ & $58.0 \pm 4.7$ & $5.0 \pm 0.2$ & $20.9 \pm 2.2$ & 3.7 & 2.9 \\
\hline $1,2,3,7,8-\mathrm{PeCDF}$ & $5 \pm 0.3$ & $44.0 \pm 9.1$ & $<1$ & $<1$ & $<0.1$ & 0.5 \\
\hline 2,3,4,7,8-PeCDF & $18 \pm 2$ & $252 \pm 54$ & $<1$ & $<1$ & 1.8 & 7.1 \\
\hline $1,2,3,4,7,8-\mathrm{HxCDF}$ & $1.3 \pm 0.1$ & $12.0 \pm 2.7$ & $1.9 \pm 0.2$ & $5.0 \pm 2.2$ & $<0.1$ & 1.5 \\
\hline $1,2,3,6,7,8-\mathrm{HxCDF}$ & $1.4 \pm 0.1$ & $16.8 \pm 4.1$ & $1.6 \pm 0.2$ & $5.4 \pm 2.3$ & $<0.1$ & 1.8 \\
\hline $1,2,3,7,8,9-\mathrm{HxCDF}$ & $<0.1$ & $0.6 \pm 0.2$ & $<1$ & $<1$ & $<0.1$ & $<0.1$ \\
\hline $2,3,4,6,7,8-\mathrm{HxCDF}$ & $1.8 \pm 0.1$ & $15.9 \pm 4$ & $<1$ & $<1$ & 0.9 & 1.1 \\
\hline $1,2,3,4,6,7,8-\mathrm{HpCDF}$ & $0.9 \pm 0.1$ & $4.5 \pm 1.5$ & $1.2 \pm 0.4$ & $5.7 \pm 1.8$ & $<0.1$ & 1.9 \\
\hline $1,2,3,4,7,8,9-\mathrm{HpCDF}$ & $0.1 \pm 0.05$ & $0.4 \pm 0.1$ & $<1$ & $<1$ & $<0.1$ & $<0.1$ \\
\hline OCDF & $0.4 \pm 0.2$ & $1.2 \pm 0.4$ & $4.5 \pm 0.7$ & $10.6 \pm 2.4$ & 1.9 & $<0.1$ \\
\hline РСB077 & $538 \pm 22$ & $1444 \pm 272$ & $48 \pm 5$ & $64 \pm 5$ & 51 & 64 \\
\hline PCB 126 & $202 \pm 29$ & $1569 \pm 463$ & $219 \pm 10$ & $513 \pm 31$ & 105 & 238 \\
\hline PCB 169 & $40 \pm 5$ & $371 \pm 89$ & $30 \pm 2$ & $100 \pm 6$ & N.D. ${ }^{4}$ & 37 \\
\hline PCB118 $\left(\mu \mathrm{g} \mathrm{kg}^{-1}\right)$ & $29 \pm 3$ & $223 \pm 20$ & $78 \pm 4$ & $219 \pm 10$ & 71 & 184 \\
\hline PCB $156\left(\mu \mathrm{g} \mathrm{kg}^{-1}\right)$ & $2 \pm 1$ & $23 \pm 2$ & $49 \pm 7$ & $219 \pm 14$ & $<1$ & 20 \\
\hline PCB $189\left(\mu \mathrm{g} \mathrm{kg}^{-1}\right)$ & $<1$ & $<1$ & $4 \pm 2$ & $9 \pm 1$ & $<1$ & $<1$ \\
\hline PCB $180\left(\mu \mathrm{g} \mathrm{kg}^{-1}\right)$ & $23 \pm 7$ & $112 \pm 7$ & $256 \pm 19$ & $770 \pm 58$ & 286 & 822 \\
\hline total $T E Q$ & $42 \pm 4$ & $426 \pm 83$ & $62 \pm 4$ & $209 \pm 12$ & 26 & 72 \\
\hline
\end{tabular}


on the basis of the mean contaminant levels in the blubber (table 1), assuming that more than $90 \%$ of lipophilic persistent contaminants are stored in the blubber layer (Hutchinson and Simmonds, 1994). Mean blubber lipid mass per seal was estimated at $15 \mathrm{~kg}$ (approximately $25 \%$ of mean body weight).

Haematology and clinical chemistry - Haematology and serum chemistry parameters were measured in blood samples taken five weeks before ("pre", week 121 of the feeding study), six weeks following ("post") and at days 8 and 15 of the fasting experiment. Haematological parameters were measured in blood with EDTA as anticoagulant on an automated haematology analyzer (Sysmex E-5000), which uses automatic windowing to discriminate between cell subsets. Clinical chemistry parameters were analyzed in serum using a selective discrete clinical chemistry analyzer (Hitachi 717). Haematology and clinical chemistry data of the seals during the feeding study are reported elsewhere (De Swart et al. 1995c).

Immunizations - At day three of the fasting experiment, seals received a booster immunization with tetanus toxoid (TT) adsorbed to aluminium phosphate (intramuscularly). All seals had been immunized with the same antigen 93 and 76 weeks earlier (weeks 33 and 50 of the feeding study, respectively (De Swart et al. 1995b)). Six weeks before the fasting experiment the seals received a primary immunization with keyhole limpet haemocyanin $(\mathrm{KLH}, 200 \mu \mathrm{g})$ adjuvanted with dimethyl-dioctadecacyl-ammoniumbromide (DDA, $800 \mu \mathrm{g})$

Figure 1: Estimated mean body burdens of organochlorines (gray bars), as percentage of estimated cumulative intakes of these chemicals (open bars) of two groups of seals $(n=2 \times 11)$ following a diet of Atlantic (A) or Baltic (B) herring for a period of two years. Cumulative intakes of the respective contaminants were estimated on the basis of contaminant levels in herring (table 1) and estimated daily lipid intakes, and are shown between brackets. Bar lengths of the cumulative intakes of the Baltic group are shown relative to the cumulative intakes of the Atlantic group. Lipid intakes were estimated at 0.45 and $0.4 \mathrm{~kg}^{-1 a y}$ for the Atlantic and Baltic groups, respectively, based on estimated daily herring intakes and lipid percentages in herring. Mean body burdens were estimated on the basis of the mean contaminant levels in the blubber (table 1), since most lipophilic persistent contaminants are largely stored in the blubber layer. Mean blubber lipid mass per seal was estimated at $15 \mathrm{~kg}$ (approximately $25 \%$ of mean body weight).

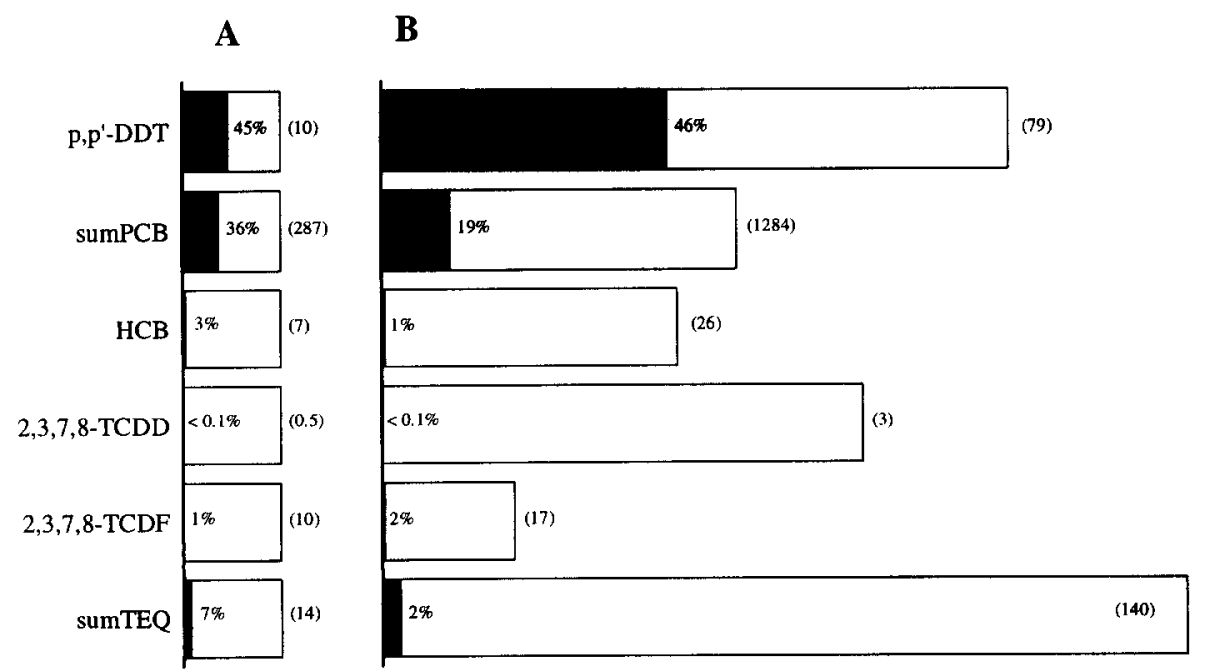

(mg)

(mg)

(mg)

Estimated body burdens as percentage of estimated cumulative intakes 
(intramuscularly). At day six of the fasting experiment the animals received a booster immunization with the same antigen / adjuvant combination.

ELISAs - Serum antibody responses to the antigens TT and KLH were measured using an enzyme linked immunosorbent assay (ELISA) as previously described (De Swart et al. 1993). Briefly, plates were coated with the respective antigens and blocked with bovine serum albumin. After incubation with serial dilutions of seal plasma (in duplicate per sample), bound IgG antibodies were detected using horseradish peroxidase labelled protein A. Results are shown as 50\% titers (sample dilution at which extinction at $450 \mathrm{~nm}$ is reduced to $50 \%$ of the maximal signal).

Immunological assays - Immunological parameters were measured following previously described methods in blood samples taken five weeks before ("pre"), six weeks following ("post") or at days 8 and 15 of the fasting experiment. Briefly, peripheral blood mononuclear cells (PBMC) were isolated from heparinized blood samples by density gradient centrifugation (De Swart et al. 1993). Cells were counted, adjusted to concentration, and assays were carried out in a double-blind manner. Natural killer cell activity was measured in a chromiumrelease assay using YAC-1 tumour cells as target (De Swart et al. 1994; Ross et al. 1995b). Lymphoproliferative responses were measured after stimulation of PBMC with optimal concentrations of the mitogens concanavalin A (Con A, $5 \mu \mathrm{g} \mathrm{ml}^{-1}$ ), pokeweed mitogen (PWM, 2.5 $\mathrm{g} \mathrm{ml}^{-1}$ ), phytohaemagglutinin-M (PHA, $20 \mu \mathrm{g} \mathrm{ml}^{-1}$ ) or

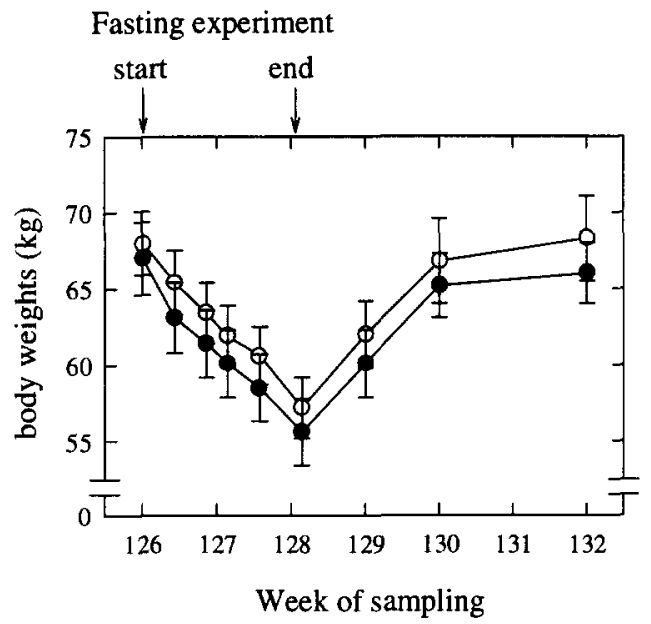

Figure 2: Body weights (means $\pm \mathrm{SE}$ ) of harbour seals of the Atlantic group (open symbols, $\mathrm{n}=11$ ) or the Baltic group (closed symbols, $n=11$ ) during a 15-day fasting period (week 126-128) and the subsequent recovery period.

lipopolysaccharide from Salmonella typhymurium (LPS, $100 \mu \mathrm{g} \mathrm{ml}^{-1}$ ), or the antigens TT (20 LF ml ${ }^{-1}$ ) or KLH $\left(20 \mu \mathrm{g} \mathrm{m}^{-1}\right)$ (De Swart et al. 1993; De Swart et al. 1994; De Swart et al. 1995b).

Hormonal assays - Serum cortisol levels were determined in a competitive fluorescence assay using europium-labeled cortisol (Pharmacia). Levels of total thyroxin (TT4) and triiodothyronine (TT3) were determined by a method based on enhanced luminescence as previously described (Murk et al. 1994).

Statistical analysis - Differences between the two dietary groups over the course of the fasting experiment were analyzed by two way ANOVA on natural log-transformed data, with time and diet as factors. Significant differences obtained with this test are shown as one $(p<0.05)$ or two $(p<0.01)$ boxed asterisks. When significant 
differences between the two groups were found in this test, differences on the individual sampling data were tested by Student's $t$ test on log-transformed data: results shown by one $(\mathrm{p}<0.05)$ or two $(\mathrm{p}<0.01)$ asterisks without box.

\section{RESULTS}

Feeding study: accumulation of immunotoxic xenobiotics - Levels of non aryl hydrocarbon $(A h)$ receptorbinding organochlorines in herring and in the blubber and blood of the seals are shown in table 1A. Sum PCB and sum DDT levels were strongly biomagnified from herring to seal blubber. Dieldrin levels were only biomagnified from herring to seal blood, but blubber levels remained relatively low. No biomagnification was observed for levels of $\mathrm{HCB}$ and $\mathrm{B}-\mathrm{HCH}$. Levels of organotin compounds and di-nitrophenol compounds in herring and seal blood were below the detection limits $\left(25 \mu \mathrm{g} \mathrm{kg}^{-1}\right.$ and $10 \mu \mathrm{g} \mathrm{kg}^{-1}$ lipid, respectively).

As shown in Table 1B, levels of $A h$ receptor-binding organochlorines (sum TEQ) in Baltic herring were approximately ten times higher than in the Atlantic herring. Total TEQ levels in the blubber of seals after two years on a diet of Baltic herring were approximately $3 \frac{1}{2}$ times higher than in the Atlantic group, but were lower than the levels measured in the Baltic herring. Total TEQ levels in blood samples of the Baltic group were even lower, although levels in the Baltic group were still a factor $2 \frac{1}{2}$ times higher than levels in the Atlantic group.

As shown in figure 1, estimated body burdens of p,p'-DDT and sum PCB (dominated by the persistent non $A h$-receptor binding congeners) were in the same order of magnitude as the estimated cumulative intakes, reflecting an efficient uptake and storage of these persistent contaminants. Estimated body burdens of HCB, 2,3,7,8-TCDD, 2,3,7,8-TCDF and sum TEQ were less than $10 \%$ of the estimated cumulative intakes of these compounds, suggesting a partial metabolization and excretion. In general, the Baltic group of seals retained a
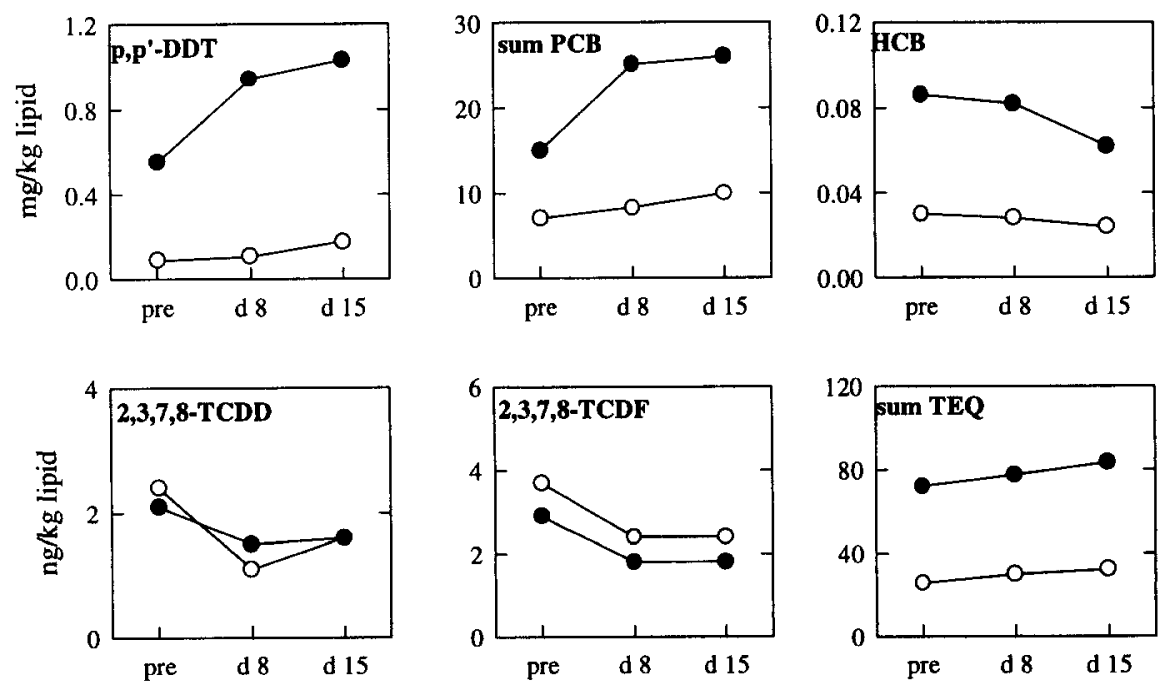

Figure 3: Levels of organochlorines (on the basis of extractable lipid) in pooled blood samples from seals of the Atlantic group (open symbols) or Baltic group (closed symbols), six weeks before ("pre"), and at days 8 and 15 of the fasting experiment. 
smaller percentage of the estimated cumulative contaminant intakes in their blubber (fig. 1 and data not shown).

Fasting experiment: mobilization of organochlorines - During the 15 day fasting experiment from week 126 onward, the seals lost $11.1 \pm 0.4 \mathrm{~kg}$, representing $16.5 \pm 0.5 \%$ of their body weight (mean $\pm \mathrm{SE}$ ). Although the body weights of the animals of the Baltic group were slightly lower at the start of the fasting experiment, the parallel course of the lines in figure 2 indicates that the weight loss was similar in both dietary groups. Throughout the fasting experiment study animals remained active and displayed a normal behaviour.

In order to get an indication of the amount of organochlorines mobilized into the bloodstream during this period, chemical analyses were carried out on pooled blood samples drawn on days 8 and 15. As shown in figure 3, blood levels of p,p'-DDT and sum PCBs showed an approximate twofold increase during the fasting experiment, while levels of HCB, 2,3,7,8-TCDD and 2,3,7,8-TCDF showed a decrease. Blood concentrations of $A h$-receptor binding organochlorines (in ng TEQ $\mathrm{kg}^{-1}$ lipid) remained largely unaffected. Levels of most 2,3,7,8-chlorine substituted dioxins and dibenzofurans stayed extremely low, ranging from below the detection limit (0.1 $\mathrm{ng} \mathrm{kg}^{-1}$ lipid) to $15 \mathrm{ng} \mathrm{kg}^{-1}$ lipid.
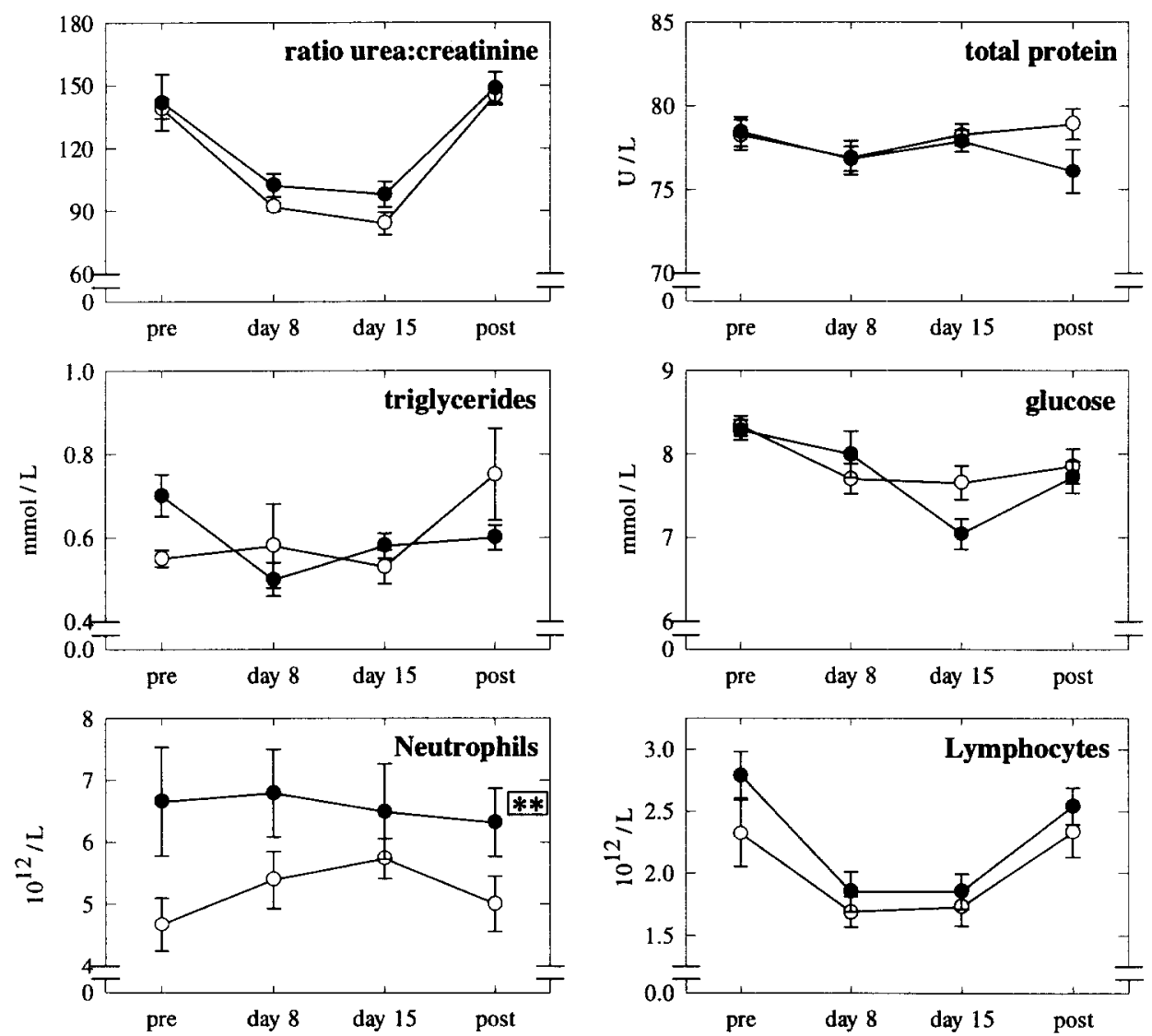

Fignre 4: Haematology and clinical chemistry parameters (means \pm SE) of seals of the Atlantic group (open symbols, $n=11$ ) or Baltic group (closed symbols, $\mathrm{n}=11$ ), six weeks before ("pre"), five weeks following ("post") and at days 8 and 15 of the fasting experiment. 
Fasting experiment: clinical chemistry and haematology - In general, haematology and clinical chemistry parameters of the seals in both groups were similarly influenced by the fasting experiment. During fasting, the ratio of serum urea to creatinine showed a decline of 30 to $40 \%$ in both groups of seals, while the fasting experiment did not strongly influence serum levels of total protein, triglycerides or glucose (fig. 4). In differential white blood cell counts, reduced numbers of circulating lymphocytes were observed in both groups of seals. Levels of neutrophils remained significantly higher (two way ANOVA, $p<0.01$ ) in seals of the Baltic group (De Swart et al. 1994; De Swart et al. 1995c), but were not influenced by fasting (fig. 4).

Fasting experiment: immunological responses - NK cell responses of PBMC isolated from seals of both dietary groups were similarly influenced by the fasting experiment. The pre-existing difference between the two dietary groups (two way ANOVA, $\mathrm{p}<0.01$ ) remained constant during and six weeks following the fasting experiment, while both groups showed an increased NK cell activity following the 15 day fasting experiment (fig. 5).

No significant differences were found in the overall PWM- or LPS-induced lymphoproliferative responses between the two groups of seals during the fasting experiment. However, Con A- and PHA-induced proliferative responses were significantly lower in the Atlantic group (fig. 6, two way ANOVA $p<0.01$ ), resulting from significantly lower responses in the seals of this group at day 15 (Student's $t$ test, $p<0.01$ ). Following booster immunizations with TT and KLH on days three and six of the fasting experiment, respectively, the overall antigen-specific humoral and lymphoproliferative responses were not significantly different between the two groups (fig. 7). It is interesting to note that all lymphoproliferative responses of the Atlantic group of seals tended to be lower than those of the Baltic group at day 15 of the fasting experiment (figs. 6,7).

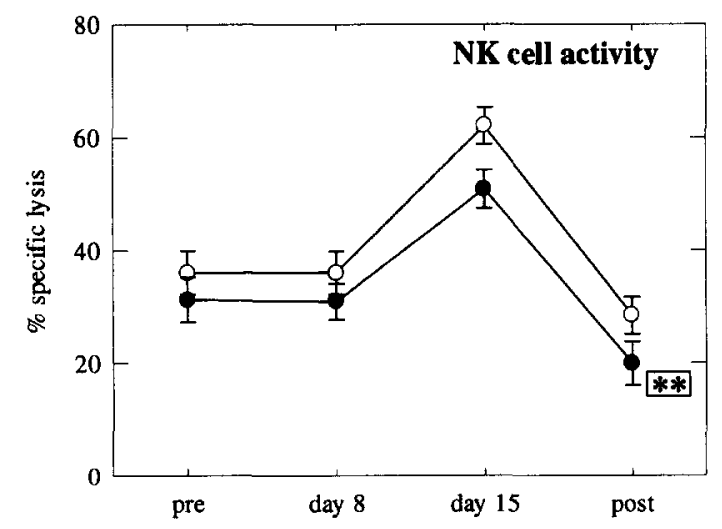

Figure 5: Natural killer (NK) cell activity
(means \pm SE) of seals of the Atlantic group
(open symbols) or the Baltic group (closed
symbols), six weeks before ("pre"), five
weeks following ("post") and at days 8 and
15 of the fasting experiment. Asterisks in
boxes indicate a significant difference
between the two dietary groups over the
course of the fasting experiment (two-way
ANOVA, p<0.01).

Fasting experiment: hormonal responses - During the fasting experiment, cortisol levels increased in both groups of seals. (fig. 8). Levels of the thyroid hormones TT4 and TT3 showed an increase in the seals of the Atlantic group on day 8 of the fasting experiment, but less so in the seals of the Baltic group (fig. 8). Serum levels of TT3 were significantly higher in the Atlantic group over the course of the fasting experiment (two way ANOVA, $\mathrm{p}<0.05$ ), and the difference was most pronounced at day 8 (Student's $t$ test, $\mathrm{p}<0.05$ ). 
Figure 6: Mitogen-induced proliferative responses of PBMC obtained from seals of the Atlantic group (open symbols) or the Baltic group (closed symbols), six weeks before ("pre"), five weeks following ("post") and at days 8 and 15 of the fasting experiment. Seal PBMC were stimulated with the $T$ cell mitogens Con A or PHA, the B cell mitogen LPS, or the $T$ and $B$ cell mitogen PWM. Proliferative responses were quantified by measuring the incorporation of ${ }^{3} \mathrm{H}$-labeled thymidine, and expressed in cpm (means $\pm \mathrm{SE}$ ), after subtraction of background responses. Asterisks in boxes indicate a significant difference between the two dietary groups over the course of the experiment (two-way ANOVA on log-transformed data, $p<0.01$ ). Asterisks without boxes indicate a significant difference between the two groups at one sampling point (Student's $t$ test, $\mathrm{p}<0.01$ ).
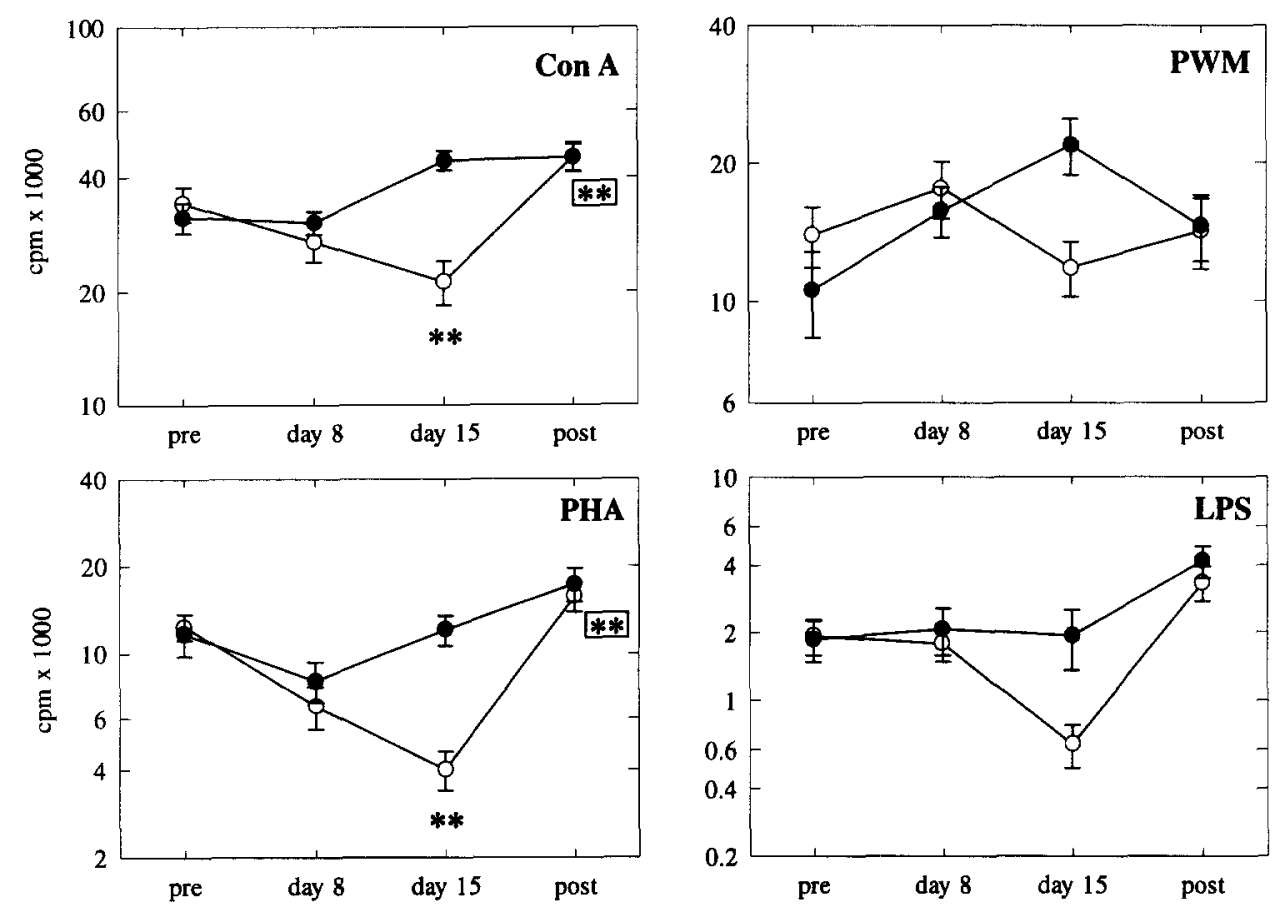

\section{DISCUSSION}

After having shown that seals fed fish contaminated through the food chain had impaired immune functions (De Swart et al. 1994; De Swart et al. 1995b; Ross et al. 1995a; Ross et al. 1995b), the present studies focussed on the bioaccumulation of potentially immunotoxic chemicals in the seals, and showed that the observed immunosuppression was not aggravated by a two week fasting.

Organochlorine levels in the herring were in line with previously published data on Baltic and Atlantic herring (Olsson and Reutergardh, 1986; Haahti and Perttilä, 1988; De Wit et al. 1992; Roots and Aps, 1993). Levels of DDTs and PCBs were strongly biomagnified from herring to seal blood and blubber, although the levels in the Baltic group were slightly below the range reported for harbour seals inhabiting the Baltic Sea (Luckas et al. 1990; Blomkvist et al. 1992; Olsson et al. 1994). This may be explained by the relatively low level perinatal contaminant exposure in our study seals. PCB and DDT levels measured in seals of the Atlantic group were within the range previously reported for seals inhabiting the north-east coast of the United Kingdom (Blomkvist et al. 1992; Hall et al. 1992). When estimated body burdens of the persistent organochlorine 
Figure 7: Antigen-specific humoral and cellular immune responses of seals of the Atlantic group (open symbols) or the Baltic group (closed symbols). Serum IgG titers (means \pm SE) following booster immunizations with tetanus toxoid at day 3 of the fasting experiment (TT, upper left) or keyhole limpet haemocyanin at day 6 of the fasting experiment (KLH, lower left) were measured in a direct ELISA using protein $A$ as a conjugate. In the left plots the fasting period is indicated by gray shading. Antigen-specific proliferative responses of PBMC (means \pm SE) were measured six weeks before ("pre"), five weeks following ("post") and at days 8 and 15 of the fasting experiment (TT-specific responses: upper right, KLH-specific responses: lower right).
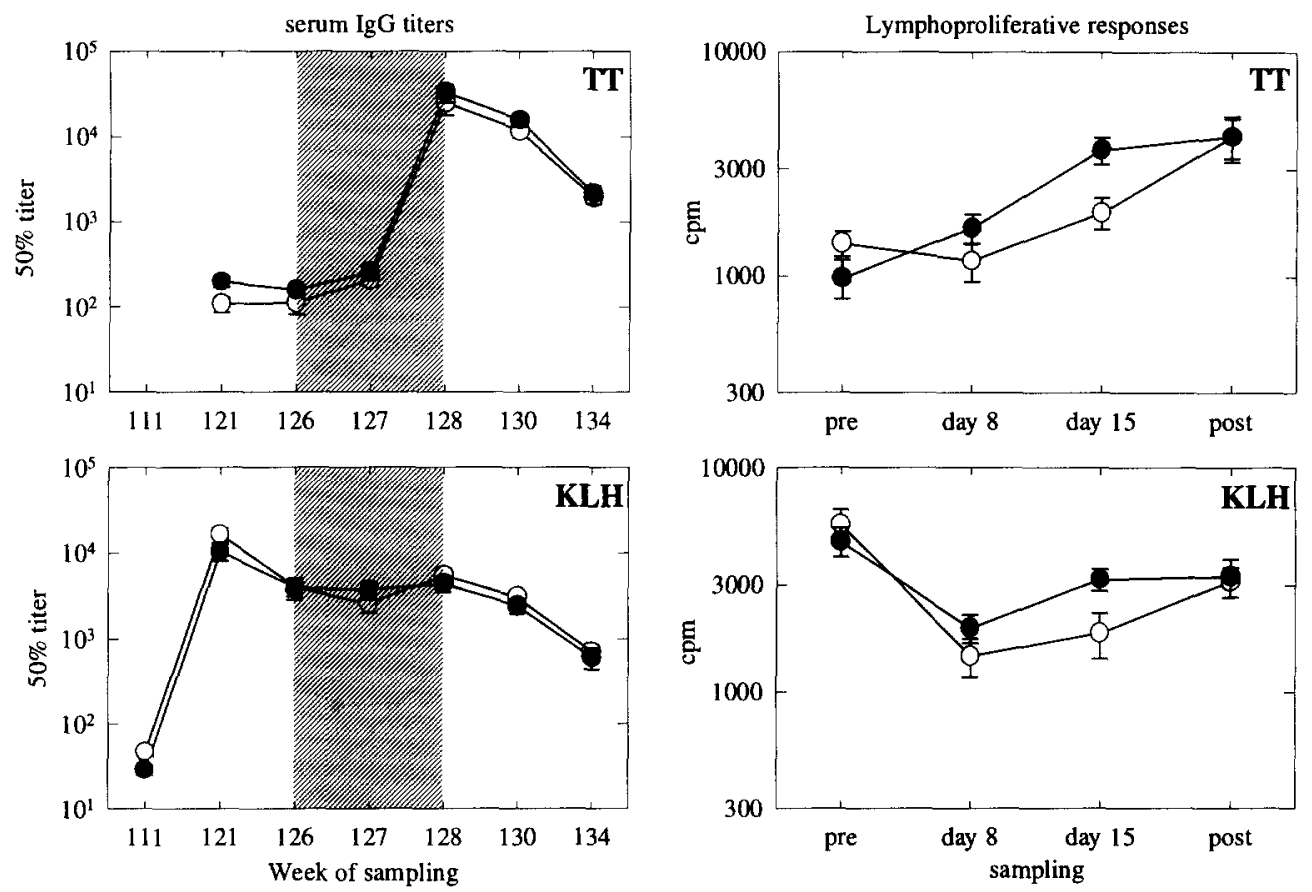

p,p'-DDT were compared with the estimated cumulative intakes during a two-year period in both groups, almost half of the estimated intake could be accounted for, suggesting that the kinetics essentially resembled those of a "closed system" (fig. 1). In agreement with previous observations (Bignert et al. 1989; Norstrom et al. 1990; De Wit et al. 1992; Bergek et al. 1992), blubber levels of PCDDs and PCDFs were relatively low, especially when compared to the estimated cumulative intakes (less than $0.1 \%$, fig. 1 ). This confirms that seals may have an efficient mechanism of either excreting or metabolizing these contaminants (Bergek et al. 1992). However, it is also possible that these compounds accumulate in other organs than in the blubber: in the rat it has been described that more than $50 \%$ of the body burdens of certain PCDD/F congeners may accumulate in the liver (Van den Berg et al. 1994). At this moment no data are available to control for this possibility: all published levels of PCDDs and PCDFs in seals are measured in blubber. In seals of the Atlantic group, generally higher percentages of the estimated cumulative intakes accumulated in the blubber. This may reflect the induction of enzyme systems (e.g. cytochrome p450) in the Baltic group, resulting in a more efficient metabolization of organochlorines (Boon et al. 1987).

Development of body weights during fasting and subsequent refeeding was similar as previously described for harbour seals (Markussen et al. 1992). During the fasting, blood levels of p,p'-DDT showed an approximate 
Figure 8: Serum levels of cortisol and levels of the thyroid hormones TT4 and TT3 (means \pm SE) of seals of the Atlantic group (open symbols) or the Baltic group (closed symbols) at days 0 ("pre"), 8 and 15 and five weeks following ("post") the fasting experiment. Asterisks in boxes indicate a significant difference between the two dietary groups over the course of the fasting experiment (two-way ANOVA on log-transformed data, $\mathrm{p}<0.05$ ). Asterisks without box indicate a significant difference between the two groups at one sampling point (Student's $t$ test, $\mathrm{p}<0.05$ ).
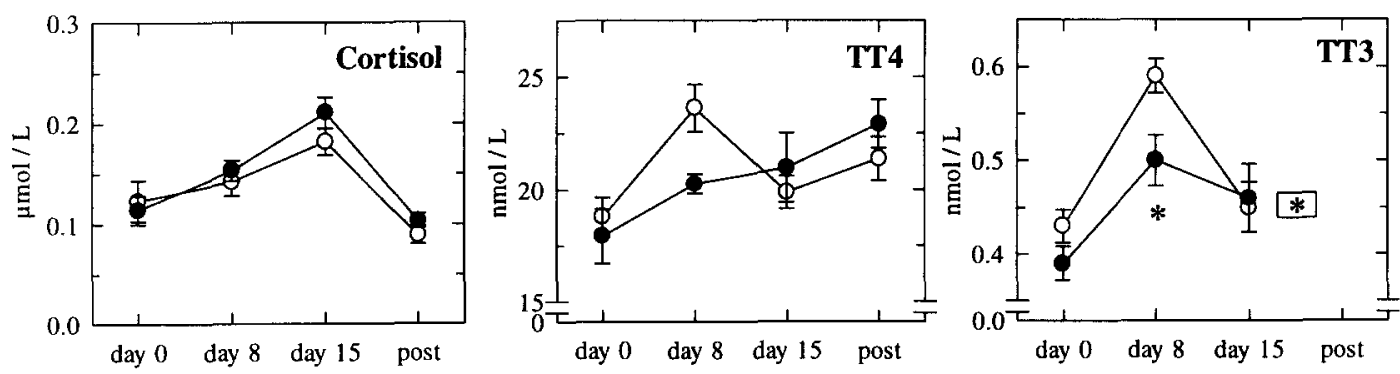

two-fold increase, suggesting that less than $1 \%$ of the total burden of this compound that was originally present in the lipids metabolized during the fasting was present in the blood. This implies that this contaminant was either not mobilized along with the metabolized lipids, or left the blood soon after mobilization, e.g. back to the blubber (Hutchinson and Simmonds, 1994; Aguilar and Borrell, 1994). However, Boon et al. (Boon et al. 1994) suggested that lipids in blubber, blood and peripheral organs essentially represent a single compartment. Assuming that p,p'-DDT cannot be metabolized by liver enzymes, the total burden of this compound should then be redistributed over the remaining body lipids. Since approximately half of the original lipid reserves were estimated to be metabolized during the fasting period, this would indeed lead to a two-fold increase in the p,p'DDT concentrations in lipids. In starved marine mammals, blubber levels of persistent organochlorines are often extremely high, indeed suggesting a concentration effect during the metabolization of blubber lipids (Blomkvist et al. 1992; Addison, 1989; Aguilar and Borrell, 1994). The lack of increasing blood levels observed for certain compounds during fasting may be explained by detoxification in the liver and subsequent excretion (Aguilar and Borrell, 1994). While the total body burden of non-metabolizable compounds like p,p'-DDT remains the same, body burdens of metabolizable compounds like the $A h$ receptor binding organochlorines may decrease during fasting. The data shown in figure 3 suggest a half-life for 2,3,7,8-TCDD of less than one week, which is shorter than the estimated half-life of this compound in most other species (van den Berg et al. 1994).

Blood levels of $A h$ receptor binding organochlorines did not increase during fasting, which is not inconsistent with our finding that only limited differences were found in functional immunological parameters measured during fasting. Numbers of circulating lymphocytes dropped to $30-40 \%$ of the initial values in both groups. Since the levels were back to normal six weeks after fasting, we speculate that this phenomenon is related to the stress of fasting. Acute stress has previously been shown to affect white blood cell counts in bottlenose dolphins (Geraci and Medway, 1973) and other mammals (Jain, 1986). The decreased serum urea:creatinine ratios in the absence of changes in serum levels of proteins, triglycerides and glucose likely reflect an adaptive response as previously observed in fasting seals (Costa and Ortiz, 1982; Castellini and Rea, 1992). 
The increased NK cell responses in both groups may also be related to fasting stress, or may alternatively have been due to the alterations in leucocyte profiles in the blood during this period: the decreased numbers of lymphocytes may have led to higher proportions of NK cells in PBMC. NK cell activity continued to be significantly lower in seals of the Baltic group as compared to the Atlantic group (De Swart et al. 1994; Ross et al. 1995b), whereas mitogen- and antigen- induced lymphoproliferative responses of these animals remained normal during fasting. Con A- and PHA- induced lymphoproliferative responses of seals of the Atlantic group were unexpectedly and unexplained reduced at day 15 .

Serum cortisol levels showed a gradual increase in both groups during fasting, which was somewhat more pronouced in the Baltic group of seals (fig. 8). Increased cortisol levels have previously been reported in harbour seals during the moulting period, which is associated with decreased food intake (Riviere et al. 1977). However, post-weaning fasting periods generally induce no or only limited changes in serum cortisol levels (Nordoy $e t$ al. 1990). The serum levels of both TT3 and TT4 increased to a larger extent in the Atlantic group than in the Baltic group. Increases in thyroid hormone levels have previously been observed in moulting harp seals (Engelhardt and Ferguson, 1980) and in the seals of this study during the moulting period (manuscript in preparation). The increase in thyroid hormone levels may be necessary to the metabolic switch to the use of blubber lipids as the principle source of energy. However, other reports have not indicated any changes in TT3 or TT4 levels during fasting in harp seals (Nordoy et al. 1993). Previously, chronic exposure to organochlorines has also been associated with reduced thyroid hormone levels in harbour seals (Brouwer et al. 1989). Irrespective of the physiological role of the increase in thyroid hormone levels during the fasting experiment, the seals of the Baltic group seemed to be less capable of this adaptive response.

Taken together, the results of our experiments indicate that although chronic exposure to environmental contaminants accumulated through the food chain leads to impaired immune function in harbour seals, relatively short-term fasting does not seem to pose a major additional immunotoxic threat to these animals. Blood levels of persistent organochlorine chemicals showed an approximate twofold increase, but levels of $A h$ receptor binding chemicals remained largely unaffected, which was in line with the fact that functional immunological assays did not provide evidence for an aggravated immunosuppression in the Baltic group. The chronic contaminant exposure influenced the endocrine response to fasting stress, as suggested by a lesser increase in serum thyroid hormone levels in the Baltic group. This suggests that marine mammals with high levels of accumulated environmental contaminants may be less able to cope with stressful situations than animals inhabiting less contaminated areas.

\section{ACKNOWLEDGEMENTS}

The authors acknowledge the help of Paul Thompson, Harry Ross, Ineke Lutke-Schipholdt, Henk Loggen, Jos Westendorp, Martin Olling, Henk Derks, Jan Boon and all collaborators of the SRRC and the DLO-IFN for their contributions to these studies. R.L. de Swart and P.S. Ross were partially funded by the Nederlandse Aardolie Maatschappij (NAM) and a Natural Sciences and Engineering Research Council of Canada award, respectively. 


\section{LITERATURE CITED}

Addison RF. Organochlorines and marine mammal reproduction. Can J Fish Aquat Sci 46: 360-368 (1989).

Aguilar A and Borrell A. Abnormally high polychlorinated biphenyl levels in striped dolphins (Stenella coeruleoalba) affected by the 1990-1992 Mediterranean epizootic. Sci Total Environ 154: 237-247 (1994).

Ahlborg UG, Becking GC, Birnbaum LS, Brouwer A, Derks HJGM, Feeley M, Golor G, Hanberg A, Larsen JC, Liem AKD, Safe SH, Schlatter C, Waern F, Younes $M$ and Yrjanheikki E. Toxic equivalency factors for dioxin-like PCBs. Chemosphere 28: 1049-1067 (1994).

Bergek S, Bergqvist P-A, Hjelt M, Olsson M, Rappe C, Roos A and Zook D. Concentrations of PCDDs and PCDFs in seals from Swedish waters. Ambio 21: 553-556 (1992).

Bergman A, Olsson M and Reiland S. Skull-bone lesions in the baltic grey seal (Halichoerus grypus). Ambio 21: $517-519$ (1992).

Bignert A, Olsson M, Bergqvist P-A, Bergek S, Rappe C, De Wit C and Jansson B. Polychlorinated dibenzo-p-dioxins (PCDD) and dibenzo-furans (PCDF) in seal blubber. Chemosphere 19: 551-556 (1989).

Blomkvist G, Roos A, Jensen S, Bignert A and Olsson M. Concentrations of sDDT and PCB in seals from Swedish and Scottish waters. Ambio 21: 539-545 (1992).

Boon JP, Reijnders PJH, Dols J, Wensvoort P and Hillebrand MTJ. The kinetics of individual polychlorinated biphenyl congeners in female harbour seals (Phoca vitulina), with evidence for structure-related metabolism. Aquat Toxicol 10: 307-324 (1987).

Boon JP, Oostingh I, Van der Meer J and Hillebrand MTJ. A model for the bioaccumulation of chlorobiphenyl congeners in marine mammals. Eur J Pharmacol-Environ Toxic 270: 237-251 (1994).

Bowen WD, Oftedal OT and Boness DJ. Mass and energy transfer during lactation in a small phocid, the harbor seal (Phoca vitulina). Physiol Zool 65: 844-866 (1992).

Brouwer A, Reijnders PJH and Koeman JH. Polychlorinated biphenyl (PCB)-contaminated fish induces vitamin $A$ and thyroid hormone deficiency in the common seal (Phoca vitulina). Aquat Toxicol 15: 99-106 (1989).

Castellini MA and Rea LD. The biochemistry of natural fasting at its limits. Experientia 48: 575-582 (1992).

Costa DP, Le Boeuf BJ, Huntley AC and Ortiz CL. The energetics of lactation in the northern elephant seal, Mirounga angustirostris. J Zool 209: 21-33 (1986).

Costa DP. Reproduction and foraging energetics of pinnipeds: implications for life history patterns. In: The behaviour of pinnipeds, edited by Renouf D. Chapman and Hall, London, pp.301-344 (1995).

Costa DP and Ortiz CL. Blood chemistry homeostasis during prolonged fasting in the northern elephant seal. Am J Physiol 242: R591-R595 (1982).

De Swart RL, Kluten RMG, Huizing CJ, Vedder LJ, Reijnders PJH, Visser IKG, UytdeHaag FGCM and Osterhaus ADME. Mitogen and antigen induced $\mathrm{B}$ and $\mathrm{T}$ cell responses of peripheral blood mononuclear cells from the harbour seal (Phoca vitulina). Vet Immunol Immunopathol 37: 217-230 (1993).

De Swart RL, Ross PS, Vedder LJ, Timmerman HH, Heisterkamp SH, Van Loveren H, Vos JG, Reijnders PJH and Osterhaus ADME. Impairment of immune function in harbor seals (Phoca vitulina) feeding on fish from polluted waters. Ambio 23: 155-159 (1994). 
De Swart RL, Harder TC, Ross PS, Vos HW and Osterhaus ADME. Morbilliviruses and morbillivirus diseases of marine mammals. Infect Agent Dis 4: 125-130 (1995a).

De Swart RL, Ross PS, Timmerman HH, Vos HW, Reijnders PJH, Vos JG and Osterhaus ADME. Impaired cellular immune response in harbour seals (Phoca vitulina) feeding on environmentally contaminated herring. Clin Exp Immunol 101: 480-486 (1995b).

De Swart RL, Ross PS, Vedder LJ, Boink FBTJ, Reijnders PJH, Mulder PGH and Osterhaus ADME. Haematology and clinical chemistry values of harbour seals (Phoca vitulina) fed environmentally contaminated herring remain within normal ranges. Can J Zool, in press (1995c).

De Wit C, Jansson B, Bergek S, Hjelt M, Rappe C, Olsson M and Andersson O. Polychlorinated dibenzo-p-dioxin and polychlorinated dibenzofuran levels and patterns in fish and fish-eating wildlife in the Baltic Sea. Chemosphere 25: 185-188 (1992).

Engelhardt FR and Ferguson JM. Adaptive hormone changes in harp seals, Phoca groenlandica, and gray seals, Halichoerus grypus, during the postnatal period. Gen Comp Endocrinol 40: $434-445$ (1980).

Geraci JR and Medway W. Simulated field blood studies in the bottle-nosed dolphin Tursiops truncatus. 2. Effects of stress on some hematologic and plasma chemical parameters. J Wildl Dis 9: 29-33 (1973).

Haahti $\mathrm{H}$ and Perttilä M. Levels and trends of organochlorines in cod and herring in the northern Baltic. Mar Pollut Bull 19: 29-32 (1988).

Hall AJ, Law RJ, Harwood J, Ross HM, Kennedy S, Allchin CR, Campbell LA and Pomeroy PP. Organochlorine levels in common seals (Phoca vitulina) which were victims and survivors of the 1988 phocine distemper epizootic. Sci Total Environ 115: 145-162 (1992).

Helle E, Olsson M and Jensen S. DDT and PCB levels and reproduction in ringed seal from the Bothnian Bay. Ambio 5: 188-189 (1976a).

Helle E, Olsson M and Jensen S. PCB levels correlated with pathological changes in seal uteri. Ambio 5: 261-263 (1976b).

Hutchinson JD and Simmonds MP. Organochlorine contamination in pinnipeds. Rev Environ Contam Toxicol 136: 123-168 (1994).

Jain N C. Schalm's veterinary hematology. Lea \& Febiger, Philadelphia, (1986).

Kuiken T, Bennett PM, Allchin CR, Kirkwood JK, Baker JR, Lockyer CH, Walton MJ and Sheldrick MC. PCBs, cause of death and body condition in harbour porpoises (Phocoena phocoena) from British waters. Aquat Toxicol 28: 13-28 (1994).

Liem AKD, De Jong APJM, Marsman JA, Den Boer AC, Groenemijer GS, Den Hartog RS, De Korte GAL, Hoogerbrugge R, Kootstra PR and Van 't Klooster HA. A rapid clean-up procedure for the analysis of polychlorinated dibenzo-p-dioxins and dibenzofurans in milk samples. Chemosphere 20: 843-850 (1990).

Luckas B, Vetter W, Fischer P, Heidemann G and Plötz J. Characteristic chlorinated hydrocarbon patterns in the blubber of seals from different marine regions. Chemosphere 21: 13-19 (1990).

Markussen NH, Ryg M and Oritsland NA. Metabolic rate and body composition of harbour seals, Phoca vitulina, during starvation and refeeding. Can J Zool 70: 220-224 (1992). 
Mortensen P, Bergman A, Bignert A, Hansen H-J, Härkönen T and Olsson M. Prevalence of skull lesions in harbor seals (Phoca vitulina) in Swedish and Danish museum collections: 1835 - 1988. Ambio 21: 520-524 (1992).

Murk AJ, Bosveld ATC, van den Berg M and Brouwer A. Effects of polyhalogenated aromatic hydrocarbons (PHAHs) on biochemical parameters in chicks of the common tern (Sterna hirundo). Aquat Toxicol 30: 91-115 (1994).

Nordoy ES, Ingebretsen OC and Blix AS. Depressed metabolism and low protein catabolism in fasting grey seal pups. Acta Physiol Scand 139: 361-369 (1990).

Nordoy ES, Aakvaag A and Larsen TS. Metabolic adaptations to fasting in harp seal pups. Physiol Zool 66: 926-945 (1993).

Norstrom RJ, Simon M and Muir DCG. Polychlorinated dibenzo-p-dioxins and dibenzofurans in marine mammals in the Canadian north. Environ Pollut 66: 1-19 (1990).

Olsson M, Karlsson B and Ahnland E. Diseases and environmental contaminants in seals from the Baltic and the Swedish west coast. Sci Total Environ 154: 217-227 (1994).

Olsson M and Reutergardh L. DDT and PCB pollution trends in the Swedish aquatic environment. Ambio 15: 103-109 (1986).

Ortiz CL, Costa DP and Le Boeuf BJ. Water and energy flux in elephant seal pups fasting under natural conditions. Physiol Zool 51: 166-178 (1978).

Osterhaus ADME and Vedder EJ. No simplification in the etiology of recent seal deaths. Ambio 18: 297-298 (1989).

Rea LD and Costa DP. Changes in standard metabolism during long-term fasting in northern elephant seal pups (Mirounga angustirostris). Physiol Zool 65: 97-111 (1992).

Reijnders PJH. Reproductive failure in common seals feeding on fish from polluted coastal waters. Nature 324: 456-457 (1986).

Riviere JE, Engelhardt FR and Solomon J. The relationship of thyroxine and cortisol to the moult of the harbor seal Phoca vitulina. Gen Comp Endocrinol 31: 398-401 (1977).

Roots $\mathrm{O}$ and Aps R. Polychlorinated biphenyls and organochlorine pesticides in Baltic herring and sprat. Toxicol Environ Chem 37: 195-205 (1993).

Ross PS, De Swart RL, Reijnders PJH, Van Loveren H, Vos JG and Osterhaus ADME. Contaminant-related suppression of delayed-type hypersensitivity and antibody responses in harbor seals fed herring from the Baltic Sea. Environ Health Perspect 103: 162-167 (1995a).

Ross PS, De Swart RL, Timmerman HH, Vedder LJ, Van Loveren H, Vos JG, Reijnders PJH and Osterhaus ADME. Suppression of natural killer cell activity in harbour seals (Phoca vitulina) fed Baltic Sea herring. Aquat Toxicol, in press (1995b).

Simmonds MP and Johnston PA. Seals, sense, and science. Mar Pollut Bull 20: 580-584 (1989).

Subramanian A, Tanabe S, Tatsukawa R, Saito S and Miyazaki N. Reduction in the testosterone levels by PCBs and DDE in Dall's porpoises of northwestern North Pacific. Mar Pollut Bull 18: 643-646 (1987). 
Tanabe S, Mori T, Tatsukawa R and Miyazaki N. Global pollution of marine mammals by PCBs, DDTs and HCHs (BHCs). Chemosphere 12: 1269-1275 (1983).

Van den Berg M, De Jongh J, Poiger H and Olson JR. The toxicokinetics and metabolism of polychlorinated dibenzo-p-dioxins (PCDDs) and dibenzofurans (PCDFs) and their relevance for toxicity. Crit Rev Toxicol 24: 1-74 (1994).

Van der Velde EG, Marsman JA, De Jong APJM, Hoogerbrugge R and Liem AKD. Analysis and occurrence of toxic planar PCBs, PCDDs and PCDFs in milk by use of carbosphere activated carbon. Chemosphere 28: 693-702 (1994).

Van Zorge JA, Van Wijnen JH, Theelen RMC, Olie K and van den Berg M. Assessment of the toxicity of mixtures of halogenated dibenzo- $p$-dioxins and dibenzofurans by use of toxicity equevalency factors (TEF). Chemosphere 19: 1881-1895 (1989).

Visser IKG, Van Bressem MF, Barrett T and Osterhaus ADME. Morbillivirus infections in aquatic mammals. Vet Res 24: 169-178 (1993). 